\title{
Violence committed against nursing staff by patients in psychiatric outpatient settings
}

\author{
Jenni Konttila1, Hanna-Mari Pesonen2 and Helvi Kyngäs1 \\ ${ }_{1}$ Faculty of Medicine, Research Unit of Nursing Science and Health Management, Medical Research \\ Center, University of Oulu Finland, Oulu and ${ }_{2}$ Centria University of Applied Sciences, Kokkola, Finland
}

This is the peer reviewed version of the following article: Konttila, J., Pesonen, H. and Kyngäs, H. (2018), Violence committed against nursing staff by patients in psychiatric outpatient settings. Int J Mental Health Nurs.

doi:10.1111/inm.12478, which has been published in final form at https://doi.org/10.1111/inm.12478.

This article may be used for non-commercial purposes in accordance with Wiley Terms and Conditions for Self-Archiving." 


\section{ABSTRACT}

Violence against nurses has increased particularly in psychiatric outpatient settings as psychiatric care shifts from being inpatient-based to being outpatient-based. Violence is a complex phenomenon that must be explored in different psychiatric nursing environments and settings. Violence in psychiatric outpatient settings should especially be explored as violence in this context has scarcely been examined. The aim of this systematic review was to elucidate violence committed against nursing staff by patients in adult psychiatric outpatient settings, based on reports from previous studies. A literature search was conducted in the CINAHL (EBSCO), Ovid MEDLINE, and PsycARTICLES (Ovid) databases. Fourteen studies emerged after the selection and quality assessment process. These studies indicated that violence in psychiatric outpatient settings is a multidimensional phenomenon comprising the reasons for, forms of, and consequences of violence. Reasons for violence could be related to the patient as well as to nursing staff. In psychiatric outpatient settings, verbal violence was the most common form of violence, and violence most frequently led to psychological consequences for nursing staff. The findings of this review highlight the importance of nursing staff developing skills and interventions for managing different kinds of violent situations. Given the multidimensional consequences of violence, attention must be given to the occupational wellbeing and coping ability of nursing staff at work. Furthermore, it would be worthwhile to compare cultural and intercountry differences of violent exposures in psychiatric outpatient settings.

Key words:

violence, psychiatric nursing, outpatient setting, nursing staff, 


\section{INTRODUCTION}

Violence against nurses has increased in healthcare settings (Choiniere et al. 2014, Gillespie et al. 2010) and particularly in psychiatric nursing (Maguire \& Ryan 2007, Nolan et al. 2001). Incidents of violence are common in psychiatric inpatient settings (McTiernan \& McDonald 2015) and have also increased in psychiatric outpatient settings (Maguire \& Ryan 2007) as mental health services shift from being inpatient-based to being outpatient-based (Ward \& Cowman 2007).

Violence may comprise physical, psychological, or verbal abuse aimed at hurting another person by causing physical injuries or psychological trauma (WHO 2002a). Inherited genes and social environments, physical and social factors, and personal characteristics all influence a person's violent behaviour (Allen et al. 2018). Biological, psychosocial, and environmental factors can cause violent behaviour (Allen et al. 2018, Rueve \& Welton 2008), and psychotic and personality disorders increase the risk of violent behaviour (Rueve \& Welton 2008).

Workplace violence is defined as an incident involving abuse, threat, or assault of staff in circumstances related to their work that aims to threaten their safety, wellbeing, or health (WHO 2002b). Healthcare professionals like nurses are potentially at high risk of workplace violence; this risk has increased and has become a global problem (WHO 2002b). An estimated 8-38\% of nursing staff experiences some kind of violence during their career (WHO 2017). Female nursing staff are at especially increased risk of falling victim to violence (Gillespie et al. 2010, WHO 2002b). Employee's age, work experience, 
and skills in managing violent situations influence the risk of falling victim to violence (Gillespie et al. 2010). Studies have also revealed cultural and intercountry differences between violent exposures (Camerino et al. 2008, Spector et al. 2014). One study suggests that organisational factors, like the type of workplace, can also influence the amount of exposure to violence (Shea et al. 2017). From the perspective of psychiatric nursing, nursing staff working in psychiatric outpatient settings may be at greater risk of workplace violence than staff working in psychiatric inpatient settings because work in outpatient settings is often independent and lonely (Nolan et al. 2001).

Previous studies report that psychiatric nurses are at greater risk of exposure to violence than nurses working in other nursing fields (Blando et al. 2013, Edward et al. 2016). Studies also highlight that exposure to violence has physical and psychological effects on victims (Maguire \& Ryan 2007, Stevenson et al. 2015, Zeng et al. 201). Workplace violence is also associated with occupational quality of life and turnover intentions (Choi \& Lee 2017). Workplace violence can also vicariously damage victim's family relationships (Najafi et al. 2017). According to studies, nursing staff require professional skills and the ability to use different kinds of preventive interventions to manage violent situations (Choiniere et al. 2014, Irwin 2006).

Violence is a complex phenomenon and must be explored in different psychiatric nursing environments and settings (Lanza et al. 2006, Otto 2000, Woods \& Ashley 2007). Many studies of violence have been conducted from the perspective of the inpatient setting (Woods \& Ashley 2007), but violence also occurs in psychiatric outpatient settings 
(Lanza et al 2006). Since, the latter is the lesser examined setting, this systematic review focused on violence committed against nursing staff by patients in outpatient settings in adult psychiatry. This review consolidated knowledge about factors related to this phenomenon of interest. Research-based knowledge of this phenomenon is important because the high risk of violence against nurses is increasing (WHO 2002b), and psychiatric services are shifting toward outpatient-based services (European commission 2008). 
AIM

The aim of this systematic review is to elucidate, based on previous studies, the violence committed against nursing staff by patients in outpatient settings in adult psychiatry. The research question was: what factors are associated with violence committed against nursing staff by patients in outpatient settings in adult psychiatry? 


\section{METHODS}

\section{Research method}

This systematic review was conducted according to the guidelines of the Centre for Reviews and Dissemination (CRD 2009). The research question was set using the PICo model, where P (population) was the nursing staff, I (phenomenon of Interest) was the violence against nursing staff committed by patients, and $\mathrm{C}$ (context) comprised the outpatient settings in adult psychiatry.

\section{Data collection}

A literature search of the following databases was conducted: CINAHL (EBSCO), Ovid MEDLINE, and PsycARTICLES (Ovid). Search terms were (community mental health OR community care), (outpatient setting*), (mental health setting* OR mental health service*), (nurs* OR service*), (psychiatric nurs* OR mental health nurs*), (mental health* OR psychiatric*), (violen* OR aggress*), (adult*), (outpatient). Search terms were based on the research question and were clarified after a preliminary search with the help of an information skills specialist. The search was conducted using different combinations of these search terms. Figure 1 shows the study selection process.

The inclusion criteria for this systematic review were based on the research question and were as follows: English or Finnish language, full-text availability, and peer-reviewed original nursing science or medical research article related to outpatient settings in adult psychiatry, or outpatient and inpatient settings in adult psychiatry if results on the outpatient settings were reported separately. No limit for methodology was set because the purpose of data collection was to gather studies with diverse methodologies and 
produce a heterogeneous dataset. A heterogeneous dataset enables versatility in examination of the investigated phenomenon (Aromataris \& Pearson 2014). The time range was set from 1997 to 2017 because psychiatric outpatient settings have increased in number over the past twenty years (Maquire \& Ryan 2007).

The critical appraisal was conducted according to the guidelines of the Joanna Briggs Institute (JBI 2014). The Qualitative Assessment Research Instrument (QARI), including ten assessment criteria, was used for quality assessment of qualitative studies and the Meta-Analysis of Statistics Assessment and Review Instrument (MAStARi), including nine assessment criteria, was used for quality assessment of quantitative studies (JBI 2014). Five or more points on a critical appraisal indicated good quality, because five points was half or more than half of the achievable points. Study selection and critical appraisal were both conducted by two researchers independently, who then communicated to reach agreement at the end of the processes. There was no disagreement between the two researchers after completion of study selection and critical appraisal. After critical appraisal, 14 studies remained for data analysis.

\section{Data analysis}

Data was extracted from the studies included (Table 1) to facilitate acquisition of the necessary information about study characteristics and findings (CRD 2009). Narrative synthesis, which aims to describe patterns across studies and analyze relationships between data, was chosen for data analysis because it is an appropriate synthesis method for clinically- or methodologically-diverse studies (CRD 2009). Narrative synthesis was conducted by first grouping the data into clusters and using colour-coding to develop a 
preliminary synthesis. Similar clusters were then combined. The conceptual mapping technique, a visual and graphical method that organises and represents knowledge using content maps (CRD 2009), was used to explore relationships between studies. Finally, the robustness of analysis was evaluated with critical reflection. The analysis identified three main factors associated with violence and the relationships between them: reasons for violence, forms of violence, and consequences of violence. 


\section{RESULTS}

Data was extracted from 14 studies. Six studies focused only on psychiatric outpatient settings and eight examined violence in both inpatient and outpatient psychiatric settings. In these latter eight studies, findings on outpatient and inpatient settings were reported separately. Study approaches included qualitative $(n=1)$ and quantitative $(n=11)$ methods and mixed methods $(n=2)$, and studies were conducted in Australia $(n=2)$, Japan $(n=1)$, Sweden $(n=2)$, and the United States of America $(n=8)$. Participants were psychiatric nursing staff in seven studies, and psychiatric patients in seven studies.

\section{Factors associated to violence}

Violence in psychiatric outpatient settings is a multidimensional phenomenon. There can be recognized reasons of violence, forms of violence and consequences of violence.

Both patients and nursing staff contributed to the reasons for violence. According to the studies included in the systematic survey, the reasons for a patient's violent behaviour include the patient's young age, prior experiences with violence (Flannery et al. 2001a, Swanson et al. 1999), substance abuse (Flannery et al. 2001a, Swanson et al. 1999), and prior history of violent behaviour (Flannery \& Walker 2001, Rao et al. 2007). Reasons for violent behaviour also include psychiatric diseases like schizophrenia (Flannery et al. 2001a, Rao et al. 2007) and personality disorders (Rao et al. 2007). Denial of services, acute psychosis, experiences with negative attitudes of the nursing staff, and medication noncompliance (Flannery et al. 2011), patient's romantic feelings toward nursing staff, and hallucinations (Flannery et al. 2001a, Flannery et al. 2011) were all reasons for 
patient's violent behavior identified from the included studies. Moreover, feelings of being unsafe could increase the risk of violent behaviour (Flannery et al. 2001a).

The studies reported that males are at greater risk of committing violent behaviour than females (Flannery et al. 2001a) but, in practice, females more frequently commit most violent attacks, excluding sexual attacks (Flannery \& Walker 2001). The patient was most often the perpetrator of violence (Tonso et al. 2016) but sometimes the perpetrator was also the patient's family member (Fujimoto et al. 2017).

Reasons one falls victim to violence from the perspective of nursing staff include: work conditions and work-environment-related physical and psychological factors such as the characteristics of the physical environment, number of staff supervisors, and work atmosphere (Soares et al. 2000). Staff member's age, duration of work experience, and staff member's views on quality of care and organisational factors like lack of resources and social support (Soares et al. 2000) all influenced the risk of falling victim to violence. Studies showed that males are at increased risk of attack by male patients, but females are at increased risk of attack by both male and female patients (Flannery et al. 2007, Flannery et al 2001b).

The most frequently-occurring form of violence was verbal violence (Flannery et al. 2001a, Fry et al. 2002, Fujimoto et al. 2017, Lewis \& Dehn 1999, Tonso et al. 2016). Nursing staff experienced verbal sexual harassment (Flannery et al. 2001a, Flannery \& Walker 2001, Fry et al. 2002, Tonso et al. 2016) and threats (Fry et al. 2002, Fujimoto et 
al. 2017). Physical violence also occurred (Flannery et al. 2001a, Flannery \& Walker 2001, Fry et al. 2002, Fujimoto et al. 2017) and sometimes involved some kind of weapon, like a knife (Fry et al. 2002, Lewis \& Dehn 1999). Studies also reported property damage and destruction (Fry et al. 2002, Fujimoto et al. 2017).

The consequences of violence were either direct or indirect. Physical violence caused immediate consequences like physical injuries (Flannery \& Walker 2001, Fry et al. 2002). Emotional reactions, like anxiety (Fry et al. 2002), emotional exhaustion (Fry et al. 2002, Tonso et al. 2016), feelings of vulnerability (Fry et al. 2002, Lewis \& Dehn 1999) and violated psychological integrity (Fry et al. 2002), are indirect consequences of violence. Violent experiences led to increased concern of loved-ones for staff members' safety (Lewis \& Dehn 1999), increased use of sick leave (Soares et al. 2000, Tonso et al. 2016), and increased risk of post-traumatic stress disorder (Fujimoto et al. 2017). Greater exposure to more forms of violence significantly increased psychological distress (Tonso et al. 2016). Sexual attacks, non-verbal intimidation, and verbal threats increased psychological fear (Flannery \& Walker 2001). Due to violence, the perpetrator could end up in psychiatric hospital (Flannery et al. 2001a).

\section{Relationships between factors associated with violence}

Examination of the relationships between the factors associated with violence revealed that the factors are strongly connected and influence each other. 
When violent situations occurred, reasons for violence, the forms of violence, and the consequences of violence were connected by place and time. Violent behaviour occurred in mental health centers (Fry et al. 2002, Swanson et al. 1999), at the perpetrator's home (Fry et al. 2002, Fujimoto et al. 2017, Swanson et al. 1999), and in other places like day centers (Fry et al. 2002). Comparisons of months, days of the week, and times of the day showed that the risk of violent behaviour increased in March, on Sunday, and during the morning time (Flannery et al. 2010).

Nursing-staff-related reasons for violent behaviour were also associated with forms of violence because females were at significantly higher risk of sexual attack, non-verbal threats, and verbal attack (Flannery \& Walker 2001). On the other hand, longer durations of work experience were associated with increased risk of sexual harassment (Fujimoto et al. 2017). Longer durations of work experience and greater numbers of monthly visits were associated with increased risk of verbal violence (Fujimoto et al. 2017). Also, reactions of nursing staff members could influence violence and the threat of violence because their ability to be present and their skills in dialogue helped with constructive handling of violent situations (Carlsson et al. 2004). Nursing staff members' psychological absence, feelings of fear, and demonstrations of feelings of fear could all escalate a violent situation (Carlsson et al. 2004). Verbal communication and body language by nursing staff were also essential for handling violent situations (Carlsson et al. 2004). 
No reported differences between aggressiveness, adherence, or compliance with treatment and patient history of violence were reported, considering the background variables associated with reasons for patient violent behaviour (Rao et al. 2007). Moreover, no differences between background variables and single factors associated with violence were reported (Flannery et al. 2011). 


\section{DISCUSSION}

This systematic review confirmed that violence committed by patients against nursing staff in psychiatric outpatient settings is a multidimensional phenomenon comprising three factors: reasons for violence, forms of violence, and consequences of violence. The findings of this review also show that these factors are connected to each other and influence each other.

The findings of this review indicate that the usual reasons for patients' violent behaviour are male gender, young age, substance use, and prior history of violence combined with psychiatric disorders like schizophrenia or personality disorder. According to Ose et al. (2017), the risk of patient violent behaviour has increased in both psychiatric inpatient and outpatient settings. In their study, patient's young age, male gender, low economic and educational status, substance use, and schizophrenia increased the risk of violent behaviour (Ose et al. 2017). Ridenour et al. (2015) examined the risk factors of workplace violence and concluded that patients' personality disorders are related to increased risk of violent behaviour. Also, patient restriction, physical assistance, and medication were reasons for violent behaviour especially in inpatient settings (Ridenour et al. 2015). Ose et al. (2017) found that the risk of violent behaviour also increased among refugees and offered the impact of sociodemographic characteristics as an explanation for this finding.

The findings of this systematic review indicate that common reasons for falling victim to violence from the perspective of the nursing staff are female gender, young age, and short durations of work experience. Edward et al. (2016) compared physical and verbal 
violence in a study and found that females are at increased risk of verbal violence while males are at increased risk of physical violence. On the other hand, Lawoko et al. (2004) highlighted in their study that physical strain derived from working conditions was associated with higher risk of being abused. Lawoko et al. (2004) also found that longer durations of work experience were associated with higher risk of being abused because staff who had worked longer had more exposure to violence.

Maquire and Ryan (2007) explored experiences with violence among nursing staff and found that education, duration of work experience, and age were associated with form of violence. For example, research managers and staff of equivalent grades reported more violent occurrences than staff nurses or students, and staff aged 40-44 years reported sexual harassment more frequently than staff aged 45 years and older or 39 years and under (Maquire and Ryan 2007). Ridenour et al. (2015) found that staff members employed at their current job for over a year experienced violence more frequently than those with less work experience. Also, Terkelsen and Larsen (2016) found that causes of violence in inpatient settings are most often related to gender, atmosphere, environment, and nursing staff members' stereotypical thinking. Najafi et al. (2017) denoted that nurses' weak communication skills and inappropriate professional communication might be antecedents of workplace aggression. The results of this systematic review also pointed out the importance of communication skills when handling violent situations.

The findings of this systematic review suggest that the reasons nursing staff fall victim to violence, from the perspective of nursing staff, may also be related to organisational 
factors. Choiniere et al. (2014) demonstrated that increased workload, a changing work environment, and lack of resources increased emotional stress, and this emotional stress influenced nursing staff members' experiences with violence. Blando et al. (2013) and Shea et al. (2017) identified a link between the characteristics of the workplace and exposure to violence. Llor-Esteban et al. (2017) studied violence in various healthcare settings and found that physical violence most commonly occurred in psychiatric units and verbal violence most commonly occurred in emergency units. Lawoko et al. (2004) found that the physical and psychological work environments can be contextual stressors and can influence experiences with violence. Lawoko et al. (2004) also highlighted the differences between experiences with violence in Sweden and in England, which may arise from differences between service systems and nursing cultures in those countries. Stevenson et al. (2015) found that, in inpatient settings, the acceptance and allowance of violence is understood as a part of nursing culture, which influences reporting of exposure to violence.

The findings of this systematic review indicate that nurses can be exposed to violence in different circumstances, for example in mental health centers, at the perpetrator's home or in day centers. This is a considerable finding, because there are intercountry differences how psychiatric outpatient services are organised. According to WHO (2014), hospital outpatient departments, mental health outpatient clinics, community mental health centers and facilities like day-care centers are ways to provide psychiatric outpatient services. Income group of countries influences strongly the availability and utilisation of psychiatric outpatient services (WHO 2014). Lawoko et al. (2004) discussed impacts of differences between English and Swedish psychiatric services to violent exposures. 
Lawoko et al. (2004) saw that team work in Sweden may protect against violence when isolated work in England increases the risk of violence. Nolan et al. (2001) discussed that in community settings nurses may even be in greater risk for violent exposures by patient's relatives because nurses collaborate more often with them. Maquire \& Ryan (2007) found differences of violent experiences in relation to service settings and service location in Ireland.

This systematic review revealed that the most common form of violence in psychiatric outpatient settings is verbal violence. Choi and Lee (2017), in their study of workplace violence, found verbal violence the most common form of violence in the field of nursing. Maquire and Ryan (2007) also found that the most common forms of violence were nonthreatening and threatening verbal violence. Nolan et al. (2001) found that the most common forms of violence in Sweden and England were verbal threats and aggressive behaviour. Physical violence, like biting, kicking, pushing, and slapping, were reported in the studies by Nolan et al. (2001), Maquire and Ryan (2007), Choi and Lee (2017), and Stevenson et al. (2015). Nolan et al. (2001) also included the possible use of weapons during violent incidents in their study. Ridenour et al. (2015) found no differences between days of the week with regards to violent occurrences. However, working the day shift increased the risk of exposure to verbal violence, and working the evening shift increased the risk of exposure to physical violence.

This systematic review identified physical and psychological consequences of violence for nursing staff. Lawoko et al. (2004) found that victims of violence reported 
psychological problems and decreased quality of care, and also highlighted that female victims reported physical health problems more often than male victims. Zeng et al. (2013) reported findings like those by Lawoko et al. (2004) while addressing connections between exposure to violence and decreased quality of physical and psychological life among psychiatric nurses. Fujishiro et al. (2011) found connections between physical and verbal violence, work-related health problems, and increased use of sick leave while exploring nurses' wellbeing at work. Choi and Lee (2017) found that exposure to violence influenced burnout and turnover among nurses and demonstrated that experiences with multiple forms of violence were related to psychological trauma. Stevenson et al. (2015) found that nurses' experiences with their own vulnerability continued many days after exposure to violence while nurses questioned their own safety at work.

The results of this systematic review did not actually emphasize cultural or intercountry differences in violent exposures. Nevertheless, there is a need to pay attention to contextual differences in the field of psychiatric nursing. According to previous studies of workplace violence in nursing, Spector et al. (2014) found that rates of physical violence and sexual harassment were highest in Anglo region whereas rates of nonphysical violence and bullying were highest in Middle East region. Rates of bullying and sexual harassment were lowest in Europe (Spector et al. 2014). Furthermore, Camerino et al. (2008) found intercountry differences while comparing eight European countries. They found that violence from patient or relatives was most common in France and rarest in The Netherlands. Also, harassment by superior or colleagues was rarest in The Netherlands whereas it was most common in Poland (Camerino et al. 2008). Spector et al. (2014) denoted that patient was most often the perpetrator of violence in Anglo and 
European regions and in Asia and Middle East regions the perpetrator was most often the patient's family member or friend. Spector et al. (2014) explained that these intercountry differences are derived from cultural taboos, values, and sensitivity. 


\section{LIMITATIONS}

This systematic review has some limitations. First, the 'psychiatric outpatient setting' was a challenging concept because various expressions of this concept exist worldwide. For this review, search terms were selected based on previous research and a preliminary search, and with the help of an information specialist from the university library. Second, in the studies included, six had the same author and comprised studies based on the same data. This definite data was quite unique and small on global level because it represented appearance of violence only in one Western country. Nevertheless, this data was based on reported patient assaults on staff. Results of these six studies represented rather restricted data which was based mainly on one researcher's interests. These may impact to the results of this systematic review by giving a greater value for a single view about this phenomenon of interest and highlighting the appearance of violence in one country. Nevertheless, all these six articles examined the phenomenon of interest from different perspectives and fulfilled the inclusion criteria of this systematic review and the criteria of quality assessment. Third, data analysis was conducted by a single researcher. This may have threatened the trustworthiness of the analysis. However, the goal of this analysis process was to avoid potential bias by aiming for accuracy and transparency, and to increase trustworthiness. Nonetheless, study selection and critical appraisal were conducted by two independent researchers who reached agreement at the end of the selection and appraisal processes. No disagreement existed between the two researchers after study selection and critical appraisal. 
Also, language bias, publication bias, and selection bias were observed in this systematic review. The language inclusion criterion was limited to English and Finnish because of the language skills of the study researchers. English is the most commonly used language in international publications. The literature search for this systematic review was conducted in diverse electronic databases to avoid publication bias. A manual literature search was omitted due to the assumption that an electronic literature search would be broad enough. The inclusion criteria were clearly and precisely defined to avoid selection bias. Also, selection of studies for inclusion in this systematic review was conducted independently by two researchers. 


\section{CONCLUSION}

\section{Relevance for clinical practice}

Acknowledging the reasons for violence in psychiatric outpatient settings is important because it can improve anticipation of the start of violent situations and prevention and control of potential escalation of violent situations. Based on the findings of this systematic review, nursing staff require professional and personal skills and preparation for managing violent situations. For example, Terkelsen and Larsen (2016) found use of dialogue important for controlling violent situations because dialogue helped create patient-oriented interactions that increased the patient's trust and feelings of safety; verbalizing a situation through dialogue was also considered helpful. Irwin et al. (2006) found that a caregiver's self-knowledge and understanding of the uniqueness of patients and situations were important for handling violent situations. Developers of nursing education and continuing education, and nursing management must be challenged to develop interventions and training programmes to increase the skills of nursing staff in dialogue.

Violence against nursing staff in psychiatric outpatient settings is most often verbal violence but can also be physical violence. From this point on, it is important that nursing staff be ready to use multiple interventions, according to a given situation, to prevent and/or manage violence and to calm patients. For example, Stevenson et al. (2015) indicated the need for different kinds of interventions for prevention of violent behaviour, and Terkelsen and Larsen (2016) stated that not all tools used by nursing staff to calm patients were necessarily suitable for every patient. 
For psychiatric outpatient settings, it is important to pay attention to the direct and indirect consequences of violence against nursing staff. Psychological consequences, in particular, influence quality of care, quality of life, occupational wellbeing, and coping at work. Physical injuries can also decrease one's physical ability to work. Choi and Lee (2017) highlighted the importance of noticing the connection between nursing staff experiences with violence and their coping with work and general quality of life. In addition, Najafi et al. (2017) highlighted the connection between experiences with violence and quality of care.

Future research examining how violence committed against nursing staff by patients occurs in different kinds of psychiatric outpatient settings and the experiences with violence encountered by nursing staff is important. Agreeing with Najafi et al. (2017), it would be important to compare cultural and intercountry differences of violent exposures. It would also be interesting to determine the meaning of the terms 'working environment' and 'working circumstances' for the occurrence of violence committed by patients against nursing staff in psychiatric outpatient settings. If possible, it would be fruitful to also examine how well and how often violent situations are reported in psychiatric outpatient settings because studies have shown that reporting may be deficient (Maquire and Ryan 2007, Stevenson et al. 2015). 


\section{REFERENCES}

Allen, J.J., Anderson, C.A. \& Bushman, B.J. (2018) The General Aggression Model. Current Opinion in Psychology, 19, 75-80.

Aromataris, E. \& Pearson, A. (2014) The systematic review: an overview. The American Journal of Nursing, 114, 53-58.

Blando, J.D., O’Hagan, E., Casteel, C., Nocera, M-A. \& Peek-Asa, C. (2013) Impact of hospital security programmes and workplace aggression on nurse perceptions of safety. Journal of Nursing Management, 21, 491-498.

Camerino, D., Estryn-Behar, M., Conway, P.M., van Der Heijden, B.I.J.M. \& Hasselhorn, H-M. (2008). Work-related factors and violence among nursing staff in the European NEXT study: A longitudinal cohort study. International Journal of Nursing Studies, 45, 35-50.

Carlsson, G., Dahlberg, K., Lützen, K. \& Nystrom, M. (2004) Violent encounters in psychiatric care: A phenomenological study of embodied caring knowledge. Issues in Mental Health Nursing, 25, 191-217.

Choi, S-E. \& Lee, H. (2017) Workplace violence against nurses in Korea and its impact on professional quality of life and turnover intention. Journal of Nursing Management, 25, 508-518. 
Choiniere, J.A., MAcDonnell, J.A., Campbell, A.L. \& Smele, S. (2014)

Conzeptualizing structural violence in the context of mental health nursing. Nursing Inquiry, 21, 39-50.

CRD, Centre for Reviews and Dissemination (2009) Systematic Reviews: CRD's guidance for undertaking reviews in health care. CRD: University of York.

Edward, K-L., Stephenson, J., Ousey, K. et al. (2016) A systematic review and meta-analysis of factors that relate to aggression perpetrated against nurses by patient/relatives or staff. Journal of Clinical Nursing, 25, 289-299.

European Commission (2008) Mental Health in the EU. Key facts, Figures, and Activities.

http://ec.europa.eu/health/ph_determinants/life_style/mental/docs/background_pape r_en.pdf. Accessed: 28 December 2017.

Flannery, R.B., Fisher, W., Walker, A.P.M., Littlewood, K.B. \& Spillane, M.J. (2001a) Nonviolent psychiatric inpatients and subsequent assaults on community patients and staff. Psychiatric Quarterly, 72, 19-27.

Flannery, R.B., Lizotte, D., Laudani, L., Staffieri, A. \& Walker, A.P (2001b) Violence against women and the Assaulted Staff Action Program. Administration and Policy in Mental Health, 28, 491-498. 
Flannery, R.B. \& Walker, P. (2001) Characteristics of Four Types of Patient Assaults: Six Year Analysis of the Assaulted Staff Action Program (ASAP). International Journal of Emergency Mental Health, 3, 211-216.

Flannery, R.B., Marks, L., Laudani, L. \& Walker, A.P. (2007) Psychiatric Patient Assault and Staff Victim Gender: Fifteen-year Analysis of the Assaulted Staff Action Program (ASAP). Psychiatric Quarterly, 78, 83-90.

Flannery, R.B., Flannery, G.J. \& Walker, P. (2010) Time of Psychiaric Patient Assaults: Twenty-Year Analysis of the Assaulted Staff Action Program (ASAP). International Journal of Emergency Mental Health, 12, 267-274.

Flannery, R.B., Staffieri, A., Hildum, S. \& Walker, P. (2011) The Violence Triad and Common Single Precipitans to Psychiatric Patient Assaults on Staff: 16-Year Analysis of the Assaulted Staff Action Program. Psychiatric Quarterly, 82, 85-93.

Fry, A.J., O’Riordan, D., Turner, M. \& Mills, K.L. (2002) Survey of aggressive incidents experienced by community mental health staff. International Journal of Mental Health Nursing, 11, 112-120.

Fujimoto, H., Hirota, M., Kodama, T., Greiner, C. \& Hashimoto, T. (2017) Violence exposure and resulting psychological effects suffered by psychiatric visiting nurses in Japan. Journal of Psychiatric and Mental Health Nursing, 24, 638-647. 
Fujishiro, K., Gee, G.C \& de Castro, A.B. (2011) Associations of Workplace Aggression With Work-Related Well-Being Among Nurses in the Philippines. American Journal of Public Health, 101, 861-867.

Gillespie, G.L, Gates, D.M., Miller, M. \& Howard, P. (2010) Workplace Violence in Healthcare Settings: Risk Factors and Protective Strategies. Rehabilitation Nursing, 35, 177-184.

Irwin, A. (2006) The nurse's role in the management of aggression. Journal of Psychiatric and Mental Health Nursing, 13, 309-318.

JBI, Joanna Briggs Institute (2014) Joanna Briggs Institute Reviewers’ Manual (2014 ed.). University of Adelaide, The Joanna Briggs Institute.

Lanza, M.L., Zeiss, R. \& Rierdan, J. (2006) Violence against psychiatric nurses: Sensitive research as science and intervention. Contemporary Nurse, 21, 71-84.

Lawoko, S., Soares, J.J.F. \& Nolan, P. (2004) Violence towards psychiatric staff: a comparison of gender, job and enviromental characteristics in England and Sweden. Work \& Stress, 18, 38-55.

Lewis, M.L. \& Dehn, D.S. (1999) Violence Against Nurses in Outpatient Mental Health Settings. Journal of Psychosocial Nursing, 37, 28-33. 
Llor-Esteban, B., Sánchez-Muñoz, M., Ruiz-Hernández, J.A. \& Jiménez-Barbero, J. (2017) User violence towards nursing professionals in mental health services and emergency units. The European Journal of Psychology Applied to Legal Context, 9 , $33-40$.

Maguire, J. \& Ryan, D. (2007) Aggression and violence in mental health services: categorizing the experiences of Irish nurses. Journal of Psychiatric and Mental Health Nursing, 14, 120-127.

McTiernan, K.\& McDonald, N. (2015) Occupational stressors, burnout and coping strategies between hospital and community psychiatric nurses in a Dublin region. Journal of Psychiatric and Mental Health Nursing, 22, 208-218.

Najafi, F., Fallahi-Khoshknab, M., Ahmadi, F., Dalvandi, A. \& Rahgozar, M. (2017) Antecendes and consequenses of workplace violence against nurses: A qualitative study. Journal of Clinical Nursing, 27, e116-e128.

Nolan, P., Soares, J., Dallender, J., Thomsen, S. \& Arnetz, B. (2001) A comparative study of the experiences of violence of English and Swedish mental health nurses. International Journal of Nursing Studies, 38, 419-426.

Ose, S.O., Lilleeng, S., Pettersen, I., Ruud, T. \& van Weeghel, J. (2017) Risk of violence among patients in psychiatric treatment: results from a national census. Nordic Journal of Psychiary, 71, 551-560. 
Otto, R.K. (2000) Assessing and Managing Violence Risk in Outpatient settings. Journal of Clinical Psychology, 56, 1239-1262.

Rao, H., Luty, J. \& Trathen, B. (2007) Characteristics of patients who are violent to staff and towards other people from a community mental health service in South East England. Journal of Psychiatric and Mental Health Nursing, 14, 753-757.

Ridenour, M., Lanza, M., Hendricks, S. et al. (2015) Incidence risk and risk factors of workplace violence on psychiatric staff. Work, 51, 19-28.

Rueve, M. E. \& Welton, R.S. (2008) Violence and Mental Illness. Psychiatry, 5, 3448.

Shea, T., Sheenan, C., Donohue, R., Cooper, B. \& De Cieri, H. (2017) Occupational Violence and Aggression Experienced by Nursing and Caring Professionals. Journal of Nursing Scholarship, 49, 236-243.

Soares, J.J.F., Lawoko, S. \& Nolan, P. (2000) The nature, extent and determinants of violence against psychiatric personnel. Work \& Stress, 14, 105-120.

Spector, P.E, Zhou, Z.E. \& Che, X.X. (2014) Nurse exposure to physical and nonphysical violence, bullying, and sexual harassment: A quantitative review. International Journal of Nursing Studies, 51, 72-84. 
Stevenson, K.N., Jack, S.M., O’Mara, L. \& LeGris, J. (2015) Registered nurses' experience of patient violence on acute care psychiatric inpatient units: an interpretive descriptive study. BMC Nursing, 17, 14-35.

Swanson, J., Borum, R., Swartz, M. \& Hiday, V. (1999) Violent Behavior Preceding Hospitalization Among Persons With Severe Mental Illness. Law and Human Behavior, 23, 185-204.

Tonso, M.A., Prematunga, R.K., Norris, S.J. et al. (2016) Workplace Violence in Mental Health: A Victorian Mental Health Workforce Survey. International Journal of Mental Health Nursing, 25, 444-451.

Terkelsen, T.B. \& Larsen, I.B. (2016) Fear, danger and aggression in a Norwegian locked psychiatric ward: Dialogue and ethics of care as contributions to cambating difficult situations. Nursing Ethics, 23, 308-317.

Ward, M. \& Cowman, C. (2007) Job satisfaction in psychiatric nursing. Journal of Psychiatric and Mental Health Nursing, 14, 454-461.

WHO, World Health Organization (2002a) World report on violence and health: summary. http://www.who.int/violence_injury_prevention/violence/world_report/en/summary _en.pdf. Accessed: 15 November 2017. 
WHO, World Health Organization (2002b) Framework guidelines for addressing workplace violence in the health sector.

http://who.int/violence_injury_prevention/violence/interpersonal/en/WVguidelinesE

N.pdf?ua=1\&ua=1. Accessed: 15 November 2017.

WHO, World Health Organization (2014) Mental Health Atlas.

http://apps.who.int/iris/bitstream/handle/10665/178879/9789241565011_eng.pdf;jse $\underline{\text { ssionid=E28E55C0F0103D61A805F79EE5498120? sequence }=1}$. Accessed: 14 April 2018.

WHO, World Health Organization (2017) Violence against health workers.

http://www.who.int/violence_injury_prevention/violence/workplace/en/. Accessed:

15 November 2017.

Woods, P. \& Ashley, C. (2007) Violence and aggression: a literature review. Journal of Psychiatric and Mental Health Nursing, 14, 652-660.

Zeng, J-Y., An, F-R., Xiang, Y-T. et al. (2013) Frequency and risk factors of workplace violence on psychiatric nurses and its impact on their quality of life in China. Psychiatry Research, 210, 510-514. 


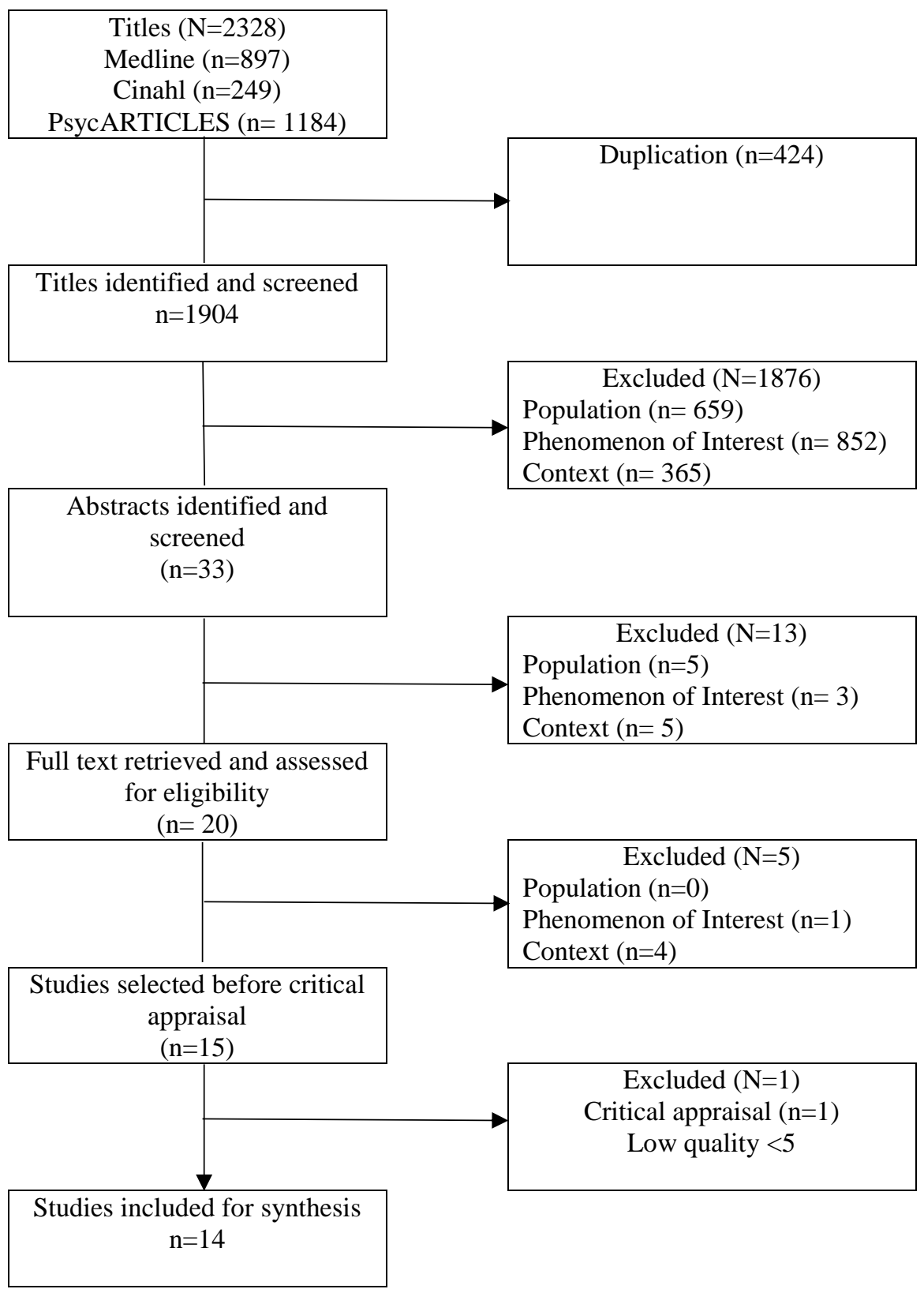

Figure 1. 


\section{Table 1.}

\begin{tabular}{|c|c|c|c|c|c|}
\hline $\begin{array}{l}\text { Original } \\
\text { studies, } \\
\text { country }\end{array}$ & Purpose & Participants & $\begin{array}{l}\text { Methodology } \\
\text { Data collection, } \\
\text { Data analysis }\end{array}$ & Key findings & $\begin{array}{l}\text { Quality } \\
\text { assessment }\end{array}$ \\
\hline $\begin{array}{l}\text { Carlsson, G. } \\
\text { Dahlberg, K. } \\
\text { Lützen, K. } \\
\text { Nystrom, M. } \\
\text { (2004) } \\
\text { Sweden }\end{array}$ & $\begin{array}{l}\text { Deepen the preliminary } \\
\text { understanding of caregiv- } \\
\text { ers' experiences with vio- } \\
\text { lent encounters in the con- } \\
\text { text of psychiatric care. } \\
\text { Deepen the understanding } \\
\text { of how caregivers, when } \\
\text { feeling threatened and ex- } \\
\text { periencing fear, continue } \\
\text { and manage the problem- } \\
\text { atic violent encounter. }\end{array}$ & $\begin{array}{l}\text { Informants } \mathrm{N}=12 \text { from a } \\
\text { psychiatric clinic and } \\
\text { community health care } \\
\text { (nurses } \mathrm{n}=2 \text {, nursing as- } \\
\text { sistants } \mathrm{n}=10 \text { ) }\end{array}$ & $\begin{array}{l}\text { Phenomenological } \\
\text { study design; } \\
\text { Re-enactment inter- } \\
\text { viewing; } \\
\text { Phenomenological anal- } \\
\text { ysis }\end{array}$ & $\begin{array}{l}\text { This study described the violent encounter as either } \\
\text { positive or negative. The positive violent encounter was } \\
\text { characterized by the caregivers' presence. The care- } \\
\text { giver was capable of handling feelings of fear through } \\
\text { inner dialogue. Dialogue gave caregivers enough cour- } \\
\text { age and strength to stay in the situation and care for the } \\
\text { patient in an appropriate benevolent way. Caregivers } \\
\text { tried to understand each patient from the patient's per- } \\
\text { spective instead of operating by their own prior under- } \\
\text { standing. The negative violent encounter is character- } \\
\text { ized by the caregivers' absence due to feelings of fear } \\
\text { before a violent encounter. Caregivers are unable to } \\
\text { handle this fear, and the unsolved fear dominates the } \\
\text { negative encounter. Caregivers who successfully en- } \\
\text { counter aggressive and violent patients are attentive to } \\
\text { the patients' needs and desires. Caregivers can balance } \\
\text { closeness to and distance from patients using verbal } \\
\text { communication and body language. }\end{array}$ & $\begin{array}{l}\text { MAStARI } \\
9 / 10\end{array}$ \\
\hline $\begin{array}{l}\text { Flannery, R.B. } \\
\text { Fisher, W. } \\
\text { Walker, A.P. } \\
\text { Littlewood, } \\
\text { K.B. } \\
\text { Spillane, M.J. } \\
\text { (2001a) } \\
\text { USA }\end{array}$ & $\begin{array}{l}\text { Provide a preliminary in- } \\
\text { quiry into the nature of } \\
\text { assaultive community-res- } \\
\text { idence patients discharged } \\
\text { from one unit of Massa- } \\
\text { chusetts state hospital } \\
\text { where there had been no } \\
\text { episodes of assault by } \\
\text { these patients for two- } \\
\text { and-half years prior to } \\
\text { their discharge. }\end{array}$ & $\begin{array}{l}\text { Clients residing in com- } \\
\text { munity-based housing } \\
\mathrm{N}=32 \text { (male } \mathrm{n}=14, \text { fe- } \\
\text { male } \mathrm{n}=18)\end{array}$ & $\begin{array}{l}\text { Retrospective study de- } \\
\text { sign; } \\
\text { Medical patient charts; } \\
\text { Statistical analyses }\end{array}$ & $\begin{array}{l}\text { During the first } 12 \text { months observed, } 16 \text { patients com- } \\
\text { mitted } 42 \text { assaults. Fifty-seven percent (57\%) of the as- } \\
\text { saults were on other patients, and } 43 \% \text { on staff. Sev- } \\
\text { enty-four percent ( } 74 \% \text { ) of assaults were verbal, } 12 \% \\
\text { sexual, } 7 \% \text { physical, and } 7 \% \text { non-verbal. Sixteen as- } \\
\text { saultive patients were primarily younger males with a } \\
\text { diagnosis of schizophrenia and a history of violence, } \\
\text { substance abuse, and personal victimization. The most } \\
\text { frequently stated reasons for the assaultive behaviour } \\
\text { included auditory hallucinations, feelings of being un- } \\
\text { safe, alcohol use, and misperceived romantic dyads. Six } \\
\text { of } 9 \text { repeatedly-assaultive patients were rehospitalized. }\end{array}$ & $\begin{array}{l}\text { MAStARI } \\
5 / 10\end{array}$ \\
\hline $\begin{array}{l}\text { Flannery, R.B. } \\
\text { Lizotte, D. } \\
\text { Laudani, L. } \\
\text { Staffieri, A. }\end{array}$ & $\begin{array}{l}\text { Revisit the first Flannery } \\
\text { inquiry into assaultive vi- } \\
\text { olence against female }\end{array}$ & $\begin{array}{l}\text { Inpatient staff-victims } \\
\mathrm{N}=465(\text { male } \mathrm{n}=250, \text { fe- } \\
\text { male } \mathrm{n}=215)\end{array}$ & $\begin{array}{l}\text { Retrospective study de- } \\
\text { sign; }\end{array}$ & $\begin{array}{l}\text { Community same-gender assaults were significantly } \\
\text { higher than community different-gender assaults. A } \\
\text { sub-analysis revealed no significant same-gender or } \\
\text { different-gender assault ratios in community residences }\end{array}$ & $\begin{array}{l}\text { MAStARI } \\
6 / 10\end{array}$ \\
\hline
\end{tabular}




\begin{tabular}{|c|c|c|c|c|c|}
\hline $\begin{array}{l}\text { Walker, A.P. } \\
(2001 b) \\
\text { USA }\end{array}$ & $\begin{array}{l}\text { staff in inpatient and com- } \\
\text { munity settings. }\end{array}$ & $\begin{array}{l}\text { Community staff-vic- } \\
\text { tims } N=241 \text { (male } \\
n=121 \text {, female } n=120 \text { ) }\end{array}$ & $\begin{array}{l}\text { Assaulted Staff Action } \\
\text { Program- reports; } \\
\text { Statistical analyses }\end{array}$ & $\begin{array}{l}\text { or community inpatient settings. Female in-patient hos- } \\
\text { pital staff were at increased risk of same-gender as- } \\
\text { saults, and female community-staff were at increased } \\
\text { risk of different-gender assaults. }\end{array}$ & \\
\hline $\begin{array}{l}\text { Flannery, R.B. } \\
\text { Walker, A.P } \\
\text { (2001c) } \\
\text { USA }\end{array}$ & $\begin{array}{l}\text { Begin to address the pos- } \\
\text { sible differential charac- } \\
\text { teristics of patient assail- } \\
\text { ants and their staff victims } \\
\text { in each of four assault cat- } \\
\text { egories. }\end{array}$ & $\begin{array}{l}\text { Inpatients and commu- } \\
\text { nity-based patients } \mathrm{N}= \\
515 \text { (male } \mathrm{n}=252, \text { fe- } \\
\text { male } \mathrm{n}=263)\end{array}$ & $\begin{array}{l}\text { Retrospective study de- } \\
\text { sign; } \\
\text { Report forms from the } \\
\text { Assaulted Patient Ac- } \\
\text { tion Program; } \\
\text { Statistical analyses }\end{array}$ & $\begin{array}{l}\text { During a 6-year period, } 529 \text { patients committed } 706 \text { as- } \\
\text { saults. Of these assaults } 66 \% \text { were inpatient and } 34 \% \\
\text { community-based. Prior history of violence, personal } \\
\text { victimization, and substance use disorder were highly } \\
\text { associated with subsequent assaults in each assaults cat- } \\
\text { egory. Females committed a significantly greater num- } \\
\text { ber of assaults (sexual assaults excluded). Female staff } \\
\text { victims were significantly more likely to fall victim to } \\
\text { sexual assaults ( } 70 \%) \text {, nonverbal intimidation ( } 75 \%) \\
\text { and verbal assaults (67\%). Physical assaults most fre- } \\
\text { quently caused physical injuries ( } 44 \%) \text {. Psychological } \\
\text { fright was the most common consequence of sexual as- } \\
\text { sault ( } 45 \%) \text {, nonverbal intimidation (100\%), and verbal } \\
\text { threats }(90 \%) \text {. }\end{array}$ & $\begin{array}{l}\text { MAStARI } \\
7 / 10\end{array}$ \\
\hline $\begin{array}{l}\text { Flannery, R.B. } \\
\text { Marks, L. } \\
\text { Laudani, L. } \\
\text { Walker, A.P. } \\
\text { (2007) } \\
\text { USA }\end{array}$ & $\begin{array}{l}\text { Examine same-gen- } \\
\text { der/different-gender as- } \\
\text { saults in one public health } \\
\text { care system during a fif- } \\
\text { teen-year period. }\end{array}$ & $\begin{array}{l}\text { Assaultive inpatients } \\
\mathrm{N}=1572 \text { (male } \mathrm{n}=806, \\
\text { female } \mathrm{n}=766) \\
\text { Assaultive community } \\
\text { patients } \mathrm{N}=531 \text { (male } \\
\mathrm{n}=241, \text { female } \mathrm{n}=290)\end{array}$ & $\begin{array}{l}\text { Retrospective study de- } \\
\text { sign; } \\
\text { Reports from the As- } \\
\text { saulted Staff Action } \\
\text { Program; } \\
\text { Statistical analyses }\end{array}$ & $\begin{array}{l}\text { There were reported totally } 1071 \text { male staff victims and } \\
1049 \text { female staff victims. Community settings reported } \\
240(45 \%) \text { male and } 290(54 \%) \text { female staff victims. In } \\
\text { community settings there were } 134(56 \%) \text { male patients } \\
\text { assault against male staff and } 105(44 \%) \text { male patients } \\
\text { assault against female staff. Numbers for female patient } \\
\text { assaults on male staff were } 108 \text { (37\%) and } 180(67 \%) \\
\text { female staff. Same-gender assaults were significantly } \\
\text { more frequent than different-gender assaults in both in- } \\
\text { patient and community settings. }\end{array}$ & $\begin{array}{l}\text { MAStARi } \\
6 / 10\end{array}$ \\
\hline $\begin{array}{l}\text { Flannery, R.B. } \\
\text { Flannery, G.J. } \\
\text { Walker, A.P. } \\
\text { (2010) } \\
\text { USA }\end{array}$ & $\begin{array}{l}\text { Continue the inquiry into } \\
\text { the temporal patterns of } \\
\text { psychiatric patient as- } \\
\text { saults on staff during a } \\
20 \text {-year period. }\end{array}$ & $\begin{array}{l}\text { Assaultive patients } \\
\mathrm{N}=2827 \text { (assaultive in- } \\
\text { patients } \mathrm{n}=2271 \text {, assaul- } \\
\text { tive patients in commu- } \\
\text { nity settings } \mathrm{n}=556 \text { ) }\end{array}$ & $\begin{array}{l}\text { Retrospective study de- } \\
\text { sign; } \\
\text { Medical charts, incident } \\
\text { reports; } \\
\text { Statistical analyses }\end{array}$ & $\begin{array}{l}\text { Most assaults occurred in community settings in March } \\
(11 \%) \text { and fewest in September }(7 \%) \text {. Seasonal differ- } \\
\text { ences between quarters were not statistically signifi- } \\
\text { cant. In community settings, } 46 \% \text { of assaults occurred } \\
\text { during days } 1 \text { through } 10 \text {. Sunday presented the highest } \\
\text { risk for assaults in community settings. The hours of } 10 \\
\text { AM and } 11 \text { AM were, in both settings, the hours of the } \\
\text { most frequent assaults. The greatest risk of assault was } \\
\text { presented during the first sift in both settings. Meal } \\
\text { times also increased the risk of violent assault. }\end{array}$ & $\begin{array}{l}\text { MAStARI } \\
6 / 10\end{array}$ \\
\hline
\end{tabular}




\begin{tabular}{|c|c|c|c|c|c|}
\hline $\begin{array}{l}\text { Flannery, R.B. } \\
\text { Staffieri, A. } \\
\text { Hildum, S. } \\
\text { Walker, A. } \\
\text { (2011) } \\
\text { USA }\end{array}$ & $\begin{array}{l}\text { Continue to examine both } \\
\text { commonly-researched } \\
\text { single precipitants and } \\
\text { then multiple precipitants } \\
\text { of the violence triad in } \\
\text { their associative relation- } \\
\text { ship with subsequent as- } \\
\text { sault in a } 16 \text {-year study of } \\
\text { patient assaults in one } \\
\text { public health sector's sys- } \\
\text { tem of care. }\end{array}$ & $\begin{array}{l}\text { Assaultive patients } \\
\mathrm{N}=2501 \text { (male } \mathrm{n}=1214 \\
\text { female } \mathrm{n}=1287)\end{array}$ & $\begin{array}{l}\text { Retrospective study de- } \\
\text { sign; } \\
\text { Medical charts, discus- } \\
\text { sions; } \\
\text { Statistical analyses }\end{array}$ & $\begin{array}{l}\text { During the } 16-\text {-year period there were } 564(22 \%) \text { com- } \\
\text { munity-based assaults and } 2002(78 \%) \text { inpatient as- } \\
\text { saults on staff. Single precipitants were: denial of ser- } \\
\text { vices }(21 \%) \text {, acute psychosis (19\%) excess sensory } \\
\text { stimulation }(12 \%) \text {, negative staff attitudes }(7 \%) \text {, medi- } \\
\text { cation noncompliance }(5 \%) \text {, commitment extension } \\
(2 \%) \text {, misdirected affection }(1 \%) \text { and other }(18 \%) \text {. } \\
\text { Clinical variables such as history of violence, personal } \\
\text { victimization, and substance use disorder were signifi- } \\
\text { cantly more frequently associated with subsequent as- } \\
\text { saults than any individual variable. Combinations of } \\
\text { clinical variables and single precipitants were not statis- } \\
\text { tically significant. }\end{array}$ & $\begin{array}{l}\text { MAStARI } \\
7 / 10\end{array}$ \\
\hline $\begin{array}{l}\text { Fry, A.J. } \\
\text { O’Riordan, D. } \\
\text { Turner, M. } \\
\text { Mills, K.L. } \\
\text { (2002) } \\
\text { Australia }\end{array}$ & $\begin{array}{l}\text { Investigate the phenome- } \\
\text { non of aggression against } \\
\text { community mental health } \\
\text { staff. }\end{array}$ & $\begin{array}{l}\text { Community mental } \\
\text { health staff } N=92 \\
\text { (nurses } n=45 \text {, reception- } \\
\text { ists } n=18 \text {, psychologists } \\
n=7 \text {, occupational thera- } \\
\text { pists } n=7 \text {, social work- } \\
\text { ers } n=7 \text {, medical offic- } \\
\text { ers } n=6 \text {, welfare officer } \\
n=1, \text { not specified } n=1 \text { ) }\end{array}$ & $\begin{array}{l}\text { Descriptive exploratory } \\
\text { design; } \\
\text { Self-report question- } \\
\text { naire; } \\
\text { Statistical analyses, } \\
\text { content analyses }\end{array}$ & $\begin{array}{l}\text { Ninety-six percent }(96 \%) \text { of respondents had experi- } \\
\text { enced some kind of aggression during the course of } \\
\text { their work. Eighty-nine percent ( } 89 \%) \text { of abuse was } \\
\text { verbal and occurred face-to-face and } 81 \% \text { occurred } \\
\text { over the telephone. Fifty-six percent (56\%) of respond- } \\
\text { ents reported threats to property and } 58 \% \text { reported ac- } \\
\text { tual damage to property. Fifty-three percent (53\%) of } \\
\text { respondents reported threats against self and } 18 \% \text { were } \\
\text { threatened with a weapon. Twenty-four percent ( } 24 \%) \\
\text { of respondents reported physical assaults without inju- } \\
\text { ries, and } 7 \% \text { reported physical injuries. Seven percent } \\
\text { (7\%) of respondents reported sexual assault and } 11 \% \\
\text { were chased. Aggressive incidents occurred most fre- } \\
\text { quently at the community centre ( } 40 \%) \text {, in private } \\
\text { homes (19\%) or at another location (14\%). Fifty-eight } \\
\text { percent (58\%) of incidents were not formally reported. } \\
\text { Emotional reactions experienced by staff were: anxiety } \\
\text { (44\%), emotional distress (35\%), feelings of vulnerabil- } \\
\text { ity, and violated psychological integrity (9\%). }\end{array}$ & $\begin{array}{l}\text { MAStARI } \\
5 / 10\end{array}$ \\
\hline $\begin{array}{l}\text { Fujimoto, H. } \\
\text { Hirota, M. } \\
\text { Kodama, T. } \\
\text { Greiner, C. } \\
\text { Hashimoto, T. } \\
\text { (2017) } \\
\text { Japan }\end{array}$ & $\begin{array}{l}\text { Clarify the experience of } \\
\text { violence among psychiat- } \\
\text { ric visiting nurses (PVNs) } \\
\text { and identify who typically } \\
\text { perpetrates the violence } \\
\text { against PVNs during vis- } \\
\text { its to people with mental } \\
\text { disorders. Clarify what }\end{array}$ & $\begin{array}{l}\text { Psychiatric visiting } \\
\text { nurses } n=94\end{array}$ & $\begin{array}{l}\text { Cross-sectional study } \\
\text { design; } \\
\text { Questionnaire; } \\
\text { Statistical analyses }\end{array}$ & $\begin{array}{l}\text { Forty-one percent ( } 41 \%) \text { of participants had experi- } \\
\text { enced some form of violence during the previous } 12 \\
\text { months. The most common forms of violence to which } \\
\text { participants were exposed during the previous } 12 \\
\text { months were: verbal abuse }(29 \%) \text {, threatening behavior } \\
(14 \%) \text {, sexual harassment }(11 \%) \text {, property damage } \\
\text { (5\%), and physical assault (4\%). The reported fre- } \\
\text { quency of exposure to violence per participant was } 1-2\end{array}$ & $\begin{array}{l}\text { MAStARI } \\
6 / 10\end{array}$ \\
\hline
\end{tabular}




\begin{tabular}{|c|c|c|c|c|c|}
\hline & $\begin{array}{l}\text { characteristics and work } \\
\text { situations among PVNs } \\
\text { were associated with vio- } \\
\text { lence exposure. Clarify } \\
\text { the resulting possible psy- } \\
\text { chological effects of vio- } \\
\text { lence exposure. }\end{array}$ & & & $\begin{array}{l}\text { times during the previous } 12 \text { months, except for verbal } \\
\text { abuse which was experienced } 3 \text { or more times in the } \\
\text { same time period. Reported violent incidents were } \\
\text { committed by patients. In one case of verbal abuse and } \\
\text { threatening behavior, the violence was committed by } \\
\text { patient and family together. Statistically significant re- } \\
\text { lationships were found between duration of experience } \\
\text { as a nurse and sexual harassment, duration of experi- } \\
\text { ence as a psychiatric home visiting nurse and verbal } \\
\text { abuse, and between number of visits per month and } \\
\text { verbal abuse. A regression model showed that verbal } \\
\text { abuse was associated with duration of career as a PVN } \\
\text { and number of visits per month. Six percent (6\%) of } \\
\text { participants had a potentially high risk of post-trau- } \\
\text { matic stress disorder (PTSD). }\end{array}$ & \\
\hline $\begin{array}{l}\text { Lewis, M.L. } \\
\text { Dehn, D.S. } \\
\text { (1999) } \\
\text { USA }\end{array}$ & $\begin{array}{l}\text { Determine the incidence } \\
\text { and severity of patient as- } \\
\text { sault, physical assault, } \\
\text { and verbal threats to } \\
\text { nurses in outpatient men- } \\
\text { tal health settings and ex- } \\
\text { amine the impact of as- } \\
\text { sault on outpatient nurses. }\end{array}$ & $\begin{array}{l}\text { Nurses in outpatient } \\
\text { psychiatric/mental } \\
\text { health facilities }(n=72)\end{array}$ & $\begin{array}{l}\text { Descriptive study de- } \\
\text { sign; } \\
\text { 25-item questionnaire; } \\
\text { Statistical analyses }\end{array}$ & $\begin{array}{l}\text { Seventeen percent }(17 \%) \text { of respondents reported a to- } \\
\text { tal of } 20 \text { physical attacks. Sixty percent }(60 \%) \text { of at- } \\
\text { tacks occurred after } 10 \text { years of outpatient practice. } \\
\text { Some kind of weapon was used in } 20 \% \text { of attacks. } \\
\text { Physical injuries were caused in } 8 \text { attacks. The impacts } \\
\text { of the assaults were: increased sense of vulnerability } \\
(58 \%) \text {, and increased concern of loved ones for nurses' } \\
\text { safety }(50 \%) \text {. Also, decreased emotional wellbeing, in- } \\
\text { creased nightmares, and decreased motivation for nurs- } \\
\text { ing were reported. Over half of respondents were ver- } \\
\text { bally threatened by a patient, and half of those were } \\
\text { verbally threatened with physical attack. Some threats } \\
\text { of physical attack were direct, some indirect. Assaulted } \\
\text { or threatened nurses were more concerned about pa- } \\
\text { tients' violent or threatening behavior than non-as- } \\
\text { saulted or non-threatened nurses. All attacks were re- } \\
\text { ported. }\end{array}$ & $\begin{array}{l}\text { MAStARI } \\
5 / 10\end{array}$ \\
\hline $\begin{array}{l}\text { Rao, H. } \\
\text { Luty, J. } \\
\text { Trathen, B. } \\
\text { (2007) } \\
\text { United Kin- } \\
\text { dom }\end{array}$ & $\begin{array}{l}\text { Compare the characteris- } \\
\text { tics of patient with and } \\
\text { without a history of vio- } \\
\text { lence in a large sample of } \\
\text { patients attending a com- } \\
\text { munity mental health ser- } \\
\text { vice in South East Eng- } \\
\text { land. }\end{array}$ & $\begin{array}{l}\text { Phase I: } \\
\text { in-patients }(\mathrm{n}=90), \\
\text { community mental } \\
\text { health team patients } \\
(\mathrm{n}=911) \text {, drug and alco- } \\
\text { hol service patients } \\
(\mathrm{n}=231) \text {, psychiatric } \\
\text { outpatients }(\mathrm{n}=576) \\
\end{array}$ & $\begin{array}{l}\text { Descriptive study de- } \\
\text { sign; } \\
\text { Semi-structured inter- } \\
\text { views including Quick } \\
\text { Personality Assessment } \\
\text { Schedule, Comprehen- } \\
\text { sive Psychopathology }\end{array}$ & $\begin{array}{l}\text { Patients' history of violence increased the rates of vio- } \\
\text { lence against health workers. Alcohol and drug-use } \\
\text { were associated with history of violence and violent be- } \\
\text { havior. Thirty-three percent ( } 33 \% \text { ) of patients with a } \\
\text { history of violence had a severe mental disorder and se- } \\
\text { vere substance use disorder. Schizophrenia and person- } \\
\text { ality disorder increased the risk of violent behavior. }\end{array}$ & $\begin{array}{l}\text { MAStARI } \\
6 / 10\end{array}$ \\
\hline
\end{tabular}




\begin{tabular}{|c|c|c|c|c|c|}
\hline & & $\begin{array}{l}\text { Phase II: } \\
\text { patients }(n=373)\end{array}$ & $\begin{array}{l}\text { Rating Scale, Alcohol } \\
\text { Use Disorder Identifica- } \\
\text { tion test; } \\
\text { Statistical analyses }\end{array}$ & $\begin{array}{l}\text { Key workers reported no differences in aggression, en- } \\
\text { gagement or adherence to care plan in those with a his- } \\
\text { tory of violence. }\end{array}$ & \\
\hline $\begin{array}{l}\text { Soares, J.J.F. } \\
\text { Lawoko, S. } \\
\text { Nolan, P. } \\
(2000) \\
\text { Sweden }\end{array}$ & $\begin{array}{l}\text { Examine the extent and } \\
\text { nature of violence experi- } \\
\text { enced by psychiatric } \\
\text { nurses and psychiatrics } \\
\text { and its relationship such } \\
\text { variables as work envi- } \\
\text { ronment. }\end{array}$ & $\begin{array}{l}\text { Mental health care per- } \\
\text { sonnel } N=1051 \\
\text { (nurses } n=731 \\
\text { psychiatrics=320), } \\
\text { in in-patient settings } \\
(n=546) \text {, outpatient set- } \\
\text { tings }(n=381) \text {, inte- } \\
\text { grated settings }(n=60) \text {, } \\
\text { emergency team }(n=16) \text {, } \\
\text { administration }(n=25), \\
\text { other }(n=9)\end{array}$ & $\begin{array}{l}\text { Cross-sectional study } \\
\text { design; } \\
\text { 14-page questionnaire; } \\
\text { Statistical analyses }\end{array}$ & $\begin{array}{l}\text { Eight-five percent }(85 \%) \text { of personnel reported expo- } \\
\text { sure of violent act over their career and } 57 \% \text { were vic- } \\
\text { tim of violence during the previous year. Ninety-seven } \\
\text { percent }(97 \%) \text { of assaults were caused by the patient. } \\
\text { Victims of violence differed from non-victims in: de- } \\
\text { mographics, work conditions and work environment, } \\
\text { views on quality of care, organisational enhancement, } \\
\text { and health. }\end{array}$ & $\begin{array}{l}\text { MAStARI } \\
6 / 10\end{array}$ \\
\hline $\begin{array}{l}\text { Swanson, J. } \\
\text { Borum, R. } \\
\text { Swartz, M. } \\
\text { Hiday, V. } \\
\text { (1999) } \\
\text { USA }\end{array}$ & $\begin{array}{l}\text { Describe the prevalence, } \\
\text { frequency, severity and } \\
\text { selected contextual fea- } \\
\text { tures in people with sev- } \\
\text { eral mental illnesses. }\end{array}$ & $\begin{array}{l}\text { Patients awaiting dis- } \\
\text { charge on outpatient } \\
\text { commitment } N=331 \text { (fe- } \\
\text { male } n=152 \text {, male } n= \\
\text { 179) }\end{array}$ & $\begin{array}{l}\text { Descriptive, epidemio- } \\
\text { logical study design; } \\
\text { Extensive, structured in- } \\
\text { terview, hospital rec- } \\
\text { ords; } \\
\text { Multivariable analyses }\end{array}$ & $\begin{array}{l}\text { Risk of exposure to violence was significantly elevated } \\
\text { among patients who were young, victims of crime, and } \\
\text { had problems with alcohol or drugs co-occurring with } \\
\text { psychiatric disorder. Two percent ( } 2 \%) \text { of respondents } \\
\text { had fought with a mental health staff member or pro- } \\
\text { vider. The most common places for violence were: the } \\
\text { home ( } 46 \%) \text { and the target's home ( } 15 \%) \text {. Ten percent } \\
(10 \%) \text { of violent occurrences occurred in hospitals and } \\
6 \% \text { in mental health centers. }\end{array}$ & $\begin{array}{l}\text { MAStARI } \\
7 / 10\end{array}$ \\
\hline $\begin{array}{l}\text { Tonso, M.A. } \\
\text { Prematunga, } \\
\text { R.K. } \\
\text { Norris, S.J. } \\
\text { Williams, L. } \\
\text { Sands, N. } \\
\text { Elsom, S.J. } \\
\text { (2016) } \\
\text { Australia }\end{array}$ & $\begin{array}{l}\text { Improve present under- } \\
\text { standings of workplace } \\
\text { violence in Victoria's } \\
\text { mental health settings. } \\
\text { Evaluate the self-reported } \\
\text { consequences of work- } \\
\text { place violence for partici- } \\
\text { pants' health. }\end{array}$ & $\begin{array}{l}\text { Mental health workers } \\
(\mathrm{n}=394) \text { in various set- } \\
\text { tings (e.g. in-patient } \\
\text { units, outpatient centers, } \\
\text { community care units) }\end{array}$ & $\begin{array}{l}\text { Exploratory descriptive } \\
\text { study design; } \\
\text { Cross-sectional survey } \\
\text { (3 different question- } \\
\text { naires); } \\
\text { Statistical analyses }\end{array}$ & $\begin{array}{l}\text { Eighty-three percent ( } 83 \% \text { )of mental health workers re- } \\
\text { ported exposure to at least one of five forms of violence } \\
\text { listed in the questionnaire. Eighty percent }(80 \%) \text { of } \\
\text { workers reported verbal abuse, } 6 \% \text { reported sexual har- } \\
\text { assment, and } 13 \% \text { reported racial harassment. Thirty- } \\
\text { four percent (34\%) of respondents were physically as- } \\
\text { saulted and } 5 \% \text { of those assaults involved weapon. The } \\
\text { perpetrator was most frequently a patient/client for vic- } \\
\text { tims of physical }(96 \%) \text {, verbal (69\%), racial ( } 73 \%) \text {, and } \\
\text { sexual (75\%) harassment or violence. Victims of vio- } \\
\text { lence usually reported multiple episodes of violence. } \\
\text { Thirty-three percent (33\%) of respondents reported } \\
\text { psychological distress. Exposure to more forms of vio- } \\
\text { lence was significantly associated with reports of psy- } \\
\text { chological distress. Exposures to violence increased the }\end{array}$ & $\begin{array}{l}\text { MAStARI } \\
7 / 10\end{array}$ \\
\hline
\end{tabular}




\begin{tabular}{|l|l|l|l|l|l|}
\hline & & & & $\begin{array}{l}\text { number of sick days used by workers compared to par- } \\
\text { ticipants with no exposure to violence. }\end{array}$ & \\
\hline
\end{tabular}

